\title{
Soil Measurements in the Context of Planning Harvesting Operations and Variable Climatic Conditions
}

\author{
Andreja Đuka ${ }^{1 *}$, Tomislav Poršinsky ${ }^{1}$, Tibor Pentek ${ }^{1}$, Zdravko Pandur $^{1}$, David Janeš ${ }^{1}$, Ivica Papa ${ }^{1}$
}

(1) University of Zagreb, Faculty of Forestry, Department of Forest Engineering, Svetošimunska 25, HR-10000 Zagreb, Croatia

*Correspondence: e-mail: aduka@sumfak.hr
Citation: ĐUKA A, PORŠINSKY T, PENTEK T, PANDUR Z, JANEŠ D, PAPA I 2018 Soil Measurements in the Context of Planning Harvesting Operations and Variable Climatic Conditions. South-east Eur for 9 (1): 61-71. DOI: https://doi.org/10.15177/ seefor.18-04

Received: 6 Oct 2017; Revised: 3 Apr 2018; 16 Apr 2018; Accepted: 26 Apr 2018; Published online: 11 May 2018

\begin{abstract}
Background and Purpose: Terrain trafficability and vehicle mobility during timber extraction are highly influenced by terrain characteristics, as well as by soil bearing capacity. Insufficient planning, too heavy vehicles, excessive traffic, poor soil knowledge, together with bad weather conditions, cause severe disturbance to forest soil. Damage to the forest ecosystem arises due to felling and timber extraction operations, regardless of the technical means used in this process. Traffic intensity plays an essential role in soil compaction because deformations can increase with the number of passes, which may lead to excessive soil disturbance.

Materials and Methods: The research was conducted in Zalesina, a hilly and pre-mountainous part of Gorski kotar, Croatia, in two management units (MUs) comprising of 569.64 ha of selective beech and fir forests. Physical and mechanical properties of forest soil, essential for vehicle mobility and terrain trafficability during timber extraction are based on measuring the following soil parameters: 1) soil penetration resistance, 2) soil shear strength, and 3) current soil moisture. Measurements were made during one calendar year, on five sampling plots (three in MU "Belevine" and two in $\mathrm{MU}$ "Kupjački vrh") chosen on the prevailing soil types in both MUs.

Results: The highest values of cone index and shear strength were recorded in July which was the warmest and driest month with only 7 rainy days. Current soil moisture was the lowest in July at $\phi=15.26 \%$ vol, while the lowest values of cone index were from October to January with precipitation at its climax from September to January with cumulative $1232 \mathrm{~mm}$ of rain and $846 \mathrm{~cm}$ of snow. Lower values of penetration resistance were in MU "Kupjački vrh" at $0.96 \mathrm{MPa}$, which is related to overall terrain structure of high karst and surface roughness, making the sampling of plots difficult. By comparing cone index values $\left(\mathrm{Cl}_{15}\right)$ and the mean values between 5 and $25 \mathrm{~cm}$ of depth $\left(\mathrm{Cl}_{5-25}\right)$, the variation coefficient indicates a lower variability of $\mathrm{Cl}_{5-25}$ values on four out of five sampling plots. However, t-test showed no statistically significant difference between these soil parameters.

Conclusions: Data regarding soil bearing capacity in a map form as an additional layer to other maps of stand characteristics would ensure better opportunities for planners or operators to reduce and avoid rutting and soil compaction. Measured data on penetration resistance, soil shear strength and current soil moisture have not only given in a simple and a fast manner the in situ stand conditions, but they have also shown their dependence on climatic conditions.
\end{abstract}

Keywords: digital penetrometer, cone index, soil shear strength, precipitation, soil moisture content

\section{INTRODUCTION}

The planning of harvesting operations usually starts with a thematically prepared maps and a pre-planned marking of stand borders and/or marking of trees. A planner besides marking cutting area borders, environmentally delicate areas and information on stand inventory needs to evaluate the best driving routes for vehicles on either temporary forest roads or trails [1], or on the existing primary and secondary forest traffic infrastructure using Geographic Information 
System (GIS). One of the most significant applications of LiDAR-derived terrain models has been in facilitating the mapping of areas of anticipated high moisture and potentially high susceptibility to soil damage by vehicles [2]. Terrain trafficability and vehicle mobility during timber extraction are highly influenced by terrain characteristics, as well as by soil bearing capacity. Insufficient planning, too heavy vehicles, excessive traffic, poor soil knowledge, together with bad weather conditions, cause severe disturbance to forest soil. Damage to the forest ecosystem arises due to felling and timber extraction operations, regardless of the technical means used in this process [3] and traffic intensity plays an essential role in soil compaction because deformations can increase with the number of passes, which may lead to excessive soil disturbance [4, 5]. Therefore, one of the most important issues in groundbased timber extraction in forestry is to minimise the soil damage caused by heavy forestry machines [6].

Soil bearing capacity is the ability of the ground to withstand external forces (wheel or track movement), and is determined by compaction, rutting and surface disturbance under external load. In forestry, soil bearing capacity is defined as the maximum permissible tire pressure of the vehicle without damaging the soil [7], depending on the type and texture of the soil, humus layer and skeletal particles (permanent parameters of soil), and the only variable parameter - soil moisture [8]. Soil bearing capacity is expressed in $\mathrm{kPa}\left(\mathrm{MPa}, \mathrm{N} \cdot \mathrm{cm}^{-2}\right)$, but there is no prescribed measurement method, due to the difficulty of accurate and straightforward procedures caused by the natural condition of forest soil, rapid changes of its moisture and the influence of the vegetation roots [9]. In terra-mechanics and wheelsoil interaction, Mohr-Coulomb's failure criterion is the most often applied one, where soil strength is quantified as the maximum permitted strain in the soil before its deformation (cracking, crushing or flowing).

Poršinsky [10] states that the share of sand and clay particles in the soil composition affects the boundary of the shear strength of soil. During vehicle movement on deformable ground, the transfer of force is relevant during load and deformation of the soil in the tangential direction, provided there is a friction between the ground and the tire. As tires of forest vehicles have mandatory treads, tangential stress is ensured in case of tread penetration into the ground. In this case, the most important feature of soil deformation is the strain because force can be achieved due to the shear strength of the soil. In general, it can be concluded that soil with the highest shear strength is over-consolidated clay or well-compacted sand, and soil with the least shear strength are poorly graded sands [10-14].

In forestry, soil bearing capacity is usually determined by the penetration of the cone into the ground and is defined as the ratio of force required to press the standardised cone, as well as varying ground resistance to penetration depending on its depth. The ground penetration curve contains data on the estimation of soil strength depending on the depth of the cone penetration, caused by the horizon condition of certain soil types. In practical application, a standardised value of the cone penetration measurement [15] is used in a $15 \mathrm{~cm}$ ground depth called the cone index $(\mathrm{Cl})$. The same standard recommends the use of a cone index when assessing terrain trafficability and the vehicles' mobility as a parameter used in modelling vehicle traction performance. However, an altered definition of the cone index can be found in literature, where the cone index is the average value of the penetration resistance measurement in the range from 0 to $15 \mathrm{~cm}$ of soil depth [16]. Horvat [12] recommends repeated measurements on forest soils due to their inhomogeneous structure, and considers penetrometer measurements as suitable for fast comparative mensuration, mainly when performed with the same penetrometer.

The first forest ground bearing capacity classification based on cone index $(\mathrm{Cl})$, shear strength and deformation modulus ( $E$ value), as each of these can be measured at once in the field using portable equipment, was made by the EcoWood project, which gave special attention to environmentally efficient timber harvesting operations on sensitive soils [17]. Poršinsky [10] and Poršinsky et al. [18], based on measurements of multiple parameters of forest soil bearing capacity in Croatia, expressed doubts about the range of the values representing high ground bearing capacity $(\mathrm{H}-\mathrm{GBC}$ ) at $>500 \mathrm{kPa}$ for cone index value; $>60 \mathrm{kPa}$ of shear strength. In accordance with the abovementioned suspicion, Poršinsky et al. [8] state that Bygdén's (2012) guideline for ground bearing capacity in forestry is more suitable for the conditions of Croatian forestry, where $\mathrm{Cl}$ values range between 700 and $1000 \mathrm{kPa}$, which is categorised as medium hard soil (may soften after rain), and $\mathrm{Cl}$ above $1000 \mathrm{kPa}$, which represents hard soil with a good bearing capacity.

Saarilahti [19] recommends that, during soil defrosting, constraints in the production system should be identified due to increased moisture and reduced soil bearing capacity, so major soil damage is reduced. Shoop et al. [20] state that the snow cover reduces soil damage, but also the systems' productivity. As the basic features of the snow cover, the authors state its thickness, temperature and density. The vehicle's mobility stops at a snow thickness of $30 \%$ of the wheel diameter, while chains on wheels enlarge mobility up to $50 \%$ of wheel diameter [21].

Access to soil data on the European level is possible via European Soil Data Centre (ESDAC). ESDAC gives topsoil physical properties for Europe (based on LUCAS topsoil data) for ca 20,000 samples across EU. Some layers for soil properties have been created based on the data from the European Soil Database in combination with data from the Harmonized World Soil Database (HWSD) and Soil-Terrain Database (SOTER) in $10 \times 10 \mathrm{~km}$ resolution. The available layers include total available water content, depth available to roots, clay content, silt content, sandy content, organic carbon, bulk density, and coarse fragments [22]. On the national level, an existing Pedological Base Map of Croatia in $1: 300,000$ scale [23] is still in use.

Talbot et al. [2] state that the development of remote and proximal sensing technology and techniques will provide a previously inconceivable amount of data. Authors continue that the machine-mounted sensors that unceasingly collect vast amounts of data will especially give the forest operation researcher a large and continually increasing basis from which to extract useful information. These data can, with the application of sensible analytical approaches, provide significant opportunities for decision 
support, as well as for operation monitoring and evaluation. Besides the advantage of the availability and use of highresolution data, prominent future development of GIS applications in forest operations could be an entirely integrated 4D spatial dataset and Virtual Reality (VR) systems [24].

This article deals with measuring soil bearing capacity through measurements of cone index, shear strength and soil moisture content to plan harvesting operations in the right period and gain more knowledge on soil properties specific for operational forestry purposes.

\section{MATERIALS AND METHODS}

\section{Study Area}

The research was conducted in Zalesina, a hilly and pre-mountainous part of Gorski kotar, Croatia, in two management units comprising of 569.64 ha of selective beech and fir forests. The average growing stock is 446 $\mathrm{m}^{3} \cdot \mathrm{ha}^{-1}$, with an annual increment of $6.83 \mathrm{~m}^{3} \cdot \mathrm{ha}^{-1}$ and a total allowable cut in the period from 2010 until 2019 at 30,565 $\mathrm{m}^{3}$.

According to Köppen climate classification, the research area belongs to the Cfsbx climatic type [25]. The essential features of the Cfsbx climatic type are cool summers with the mean temperature of the hottest month below $22^{\circ} \mathrm{C}$, while the average monthly cool summer temperature ranges from $-3^{\circ} \mathrm{C}$ to $+18^{\circ} \mathrm{C}$. In the research area chilled air masses are retained due to its geographic position in a wet and closed plateau, leading to a low average annual temperature of just $6.8^{\circ} \mathrm{C}$. Zalesina is abundant with precipitation, with annual average values up to $2074 \mathrm{~mm}$ in 136 days of precipitation and with two yearly minimums, one at the end of winter - in March with average precipitation of $140 \mathrm{~mm}$, and the other one in summer - in July with average precipitation of 143 $\mathrm{mm}$ [26]. Climate elements affect harvesting operations, which may be best reflected by the data on the highest daily precipitation. Thus, in one day up to $154 \mathrm{~mm}$ of rain may fall (data from September 1951) in the form of strong showers, which is the same amount of precipitation in June. Therefore, soil protection from erosion and torrents is necessary. A significant share of annual precipitation is significant for late autumn and winter, which consists of 98 days with snow, while the snowfall lasts on average 188 days (from the end of October to the end of June). There is also a significant proportion of snowfall in annual precipitation, up to $26 \%$, so that in spring the melting of snow significantly soaks the forest soil.

In the two adjacent management units (MUs) "Belevine" and "Kupjački vrh", both with natural fir and beech forests, managed in selective cuts, variations in terrain conditions are evident. The relief of $\mathrm{MU}$ "Belevine" is mildly undulating and fan-like striated with many beds of water streams with their steep sides affecting timber extraction routes. MU does not contain stoniness, rockiness or similar ground obstacles. Terrain slope on $55.73 \%$ of the MU is between $0-20 \%$ [27]. Terrain conditions and harvesting system in use resulted in a skid trail network for timber extraction by a skidder.
In the MU "Kupjački vrh", karst phenomena and cliffs are common, with a centrally located peak at $997 \mathrm{~m}$ and with hillsides descending in all directions. More than $50 \%$ of the MU has terrain slopes higher than $34 \%$, and $65.87 \%$ of $\mathrm{MU}$ is categorised as having uneven to very rough terrain regarding stoniness and rockiness [28]. This all resulted in a built skid road network without which skidders' mobility in this MU would be unattainable [29].

\section{Measuring Equipment}

Physical and mechanical properties of forest soil essential for vehicle mobility and terrain trafficability during timber extraction are based on measuring the following soil parameters: 1) soil penetration resistance, 2) soil shear strength, and 3) current soil moisture. Measurements were made during one calendar year, on five sampling plots (three in $\mathrm{MU}$ "Belevine" and two in MU "Kupjački vrh") chosen on the prevailing soil types in both MUs (Figure 1):

- BEL 1 - dystric colluvial brown soil

- BEL 2 - dystric brow soil (typically brown podzolic)

- BEL 3 - deep dystric brown soil

- KUP 1 - shallow rendzina

- KUP 2 - shallow and medium deep rendzina

A digital penetrometer Eijkelkamp Penetrologger was used to measure penetration with a cone surface range of $2 \mathrm{~cm}^{2}$ and the angle of cone at $30^{\circ}$ according to the standard ASAE S.313.3 at a penetration speed of $2 \mathrm{~s} \cdot \mathrm{cm}^{-1}$. The measurements were performed on a monthly basis in 15 repetitions per plot at a depth of maximal $80 \mathrm{~cm}$. Soil bearing capacity was defined by cone index as a derivative of soil penetration resistance at $15 \mathrm{~cm}$ depth [15].

For measuring soil shear strength, Eijkelkamp Field inspection vane tester was used with $20 \times 40 \mathrm{~mm}$ wing dimension, a measuring range of 0 to $130 \mathrm{kP}$, and a reading accuracy of $2 \mathrm{kPa}$. The measurements were performed on a monthly basis in 15 repetitions per plot at a depth of $15 \mathrm{~cm}$.

The current soil moisture was measured by a Fieldscount TDR 300 soil moisture meter at a depth of 15 $\mathrm{cm}$. Measurements were made in repetitions of 15 on all five surface plots, with each of the 15 measurements being the average of 10 measurements so that 150 current moisture data were measured on each plot.

From the State Meteorological and Hydrological Service data on average daily temperatures $\left({ }^{\circ} \mathrm{C}\right)$; average daily wind power $\left(\mathrm{m} \cdot \mathrm{s}^{-1}\right)$; daily height of total snow $(\mathrm{cm})$; daily precipitation $(\mathrm{mm})$; and daily insolation (hours) were taken for the analysis and better understanding of the soil bearing capacity dynamics during the year.

\section{RESULTS}

According to the national hydro-meteorological data, there were no discrepancies in temperature for autumn and winter in the measuring period, but the amount of precipitation varied. Spring was characterised as warm to very warm (higher values by $0.8-1.5^{\circ} \mathrm{C}$ ) and precipitation was normal $(101 \%)$ to dry $(67 \%)$. Summer was extremely warm (temperatures higher by $1.7^{\circ} \mathrm{C}$ ) with normal amount of precipitation at $101 \%$. 


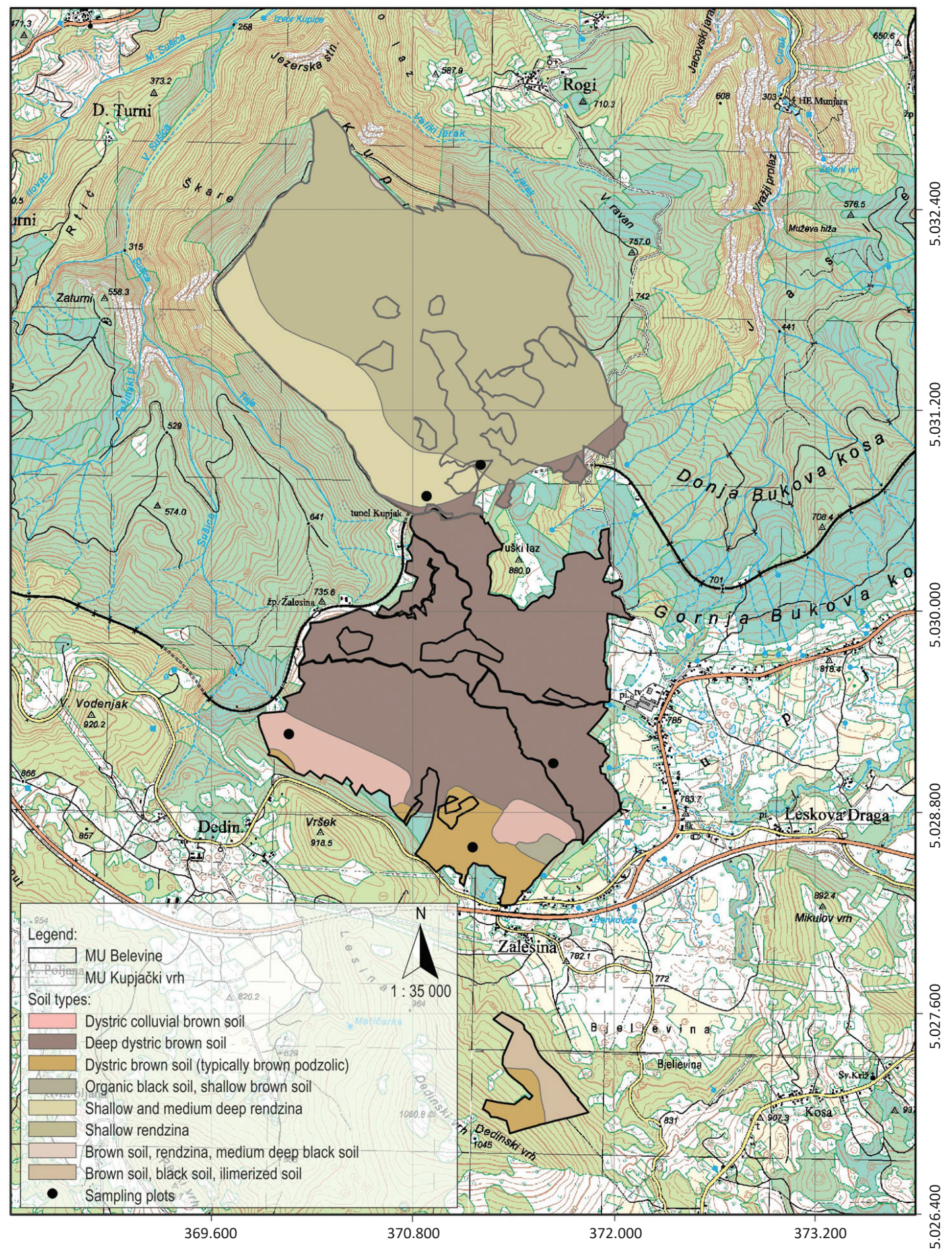

FIGURE 1. Study area 


\section{Soil Moisture Content}

By a repeated ANOVA analysis made in software Statistica 13.1, a statistically significant difference between sampling plots and the period of measurements were determined (Table 1).

Tukey Post Hoc test (Table 2) showed statistically significant difference between some sampling plots with MS=26.747 and $d f=70$.

Figure 1 shows difference in values regarding the time of measurements (month) and location (sampling plot). The highest average monthly moisture values were recorded in October, and the lowest values in July. There were no field measurements in December due to high snow which prevented approach to the sampling plots.

Figure 3 comprises the climatic data (precipitation amount and snow) together with soil moisture data during twelve months of measurements. The peak of soil moisture content was from September to November on average $\phi=39.10 \%$, which correlates to the high amount of precipitation above $272 \mathrm{~mm}$.

TABLE 1. Repeated ANOVA of current soil moisture measurements (* symbolises significant difference).

\begin{tabular}{|c|c|c|c|c|c|}
\hline Effect & SS & DF & MS & $\mathbf{F}$ & p \\
\hline Intercept & $752758.7^{*}$ & $1^{*}$ & $752758.7^{*}$ & $28143.40^{*}$ & $0.00^{*}$ \\
\hline Sampling plot & $7561.5^{*}$ & $4^{*}$ & $1890.4^{*}$ & $70.68^{*}$ & $0.00^{*}$ \\
\hline Error & 1872.3 & 70 & 26.7 & & \\
\hline Period of measurements & $60162.4^{*}$ & $11^{*}$ & $5469.3^{*}$ & $329.96 *$ & $0.00^{*}$ \\
\hline Sampling plot * Period of measurements & $13605.0^{*}$ & $44^{*}$ & $309.2^{*}$ & $18.65^{*}$ & $0.00^{*}$ \\
\hline Error & 12763.3 & 770 & 16.6 & & \\
\hline
\end{tabular}

TABLE 2. Tukey Post Hoc test of soil moisture content (* symbolises significant difference).

\begin{tabular}{cccccc}
\hline Sampling plot & BEL 1 & BEL 2 & BEL 3 & KUP 1 & KUP 2 \\
29.420 & $\mathbf{3 1 . 3 7 9}$ & $\mathbf{2 3 . 3 0 2}$ & $\mathbf{3 0 . 8 0 0}$ \\
\hline BEL 1 & & $0.005405^{*}$ & $0.000125^{*}$ & 0.985381 & 0.095375 \\
BEL 2 & $0.005405^{*}$ & & $0.000125^{*}$ & $0.024281^{*}$ & 0.825289 \\
BEL 3 & $0.000125^{*}$ & $0.000125^{*}$ & & $0.000125^{*}$ & $0.000125^{*}$ \\
KUP 1 & 0.985381 & $0.024281^{*}$ & $0.000125^{*}$ & & 0.270384 \\
KUP 2 & 0.095375 & 0.825289 & $0.000125^{*}$ & 0.270384 & \\
\hline
\end{tabular}

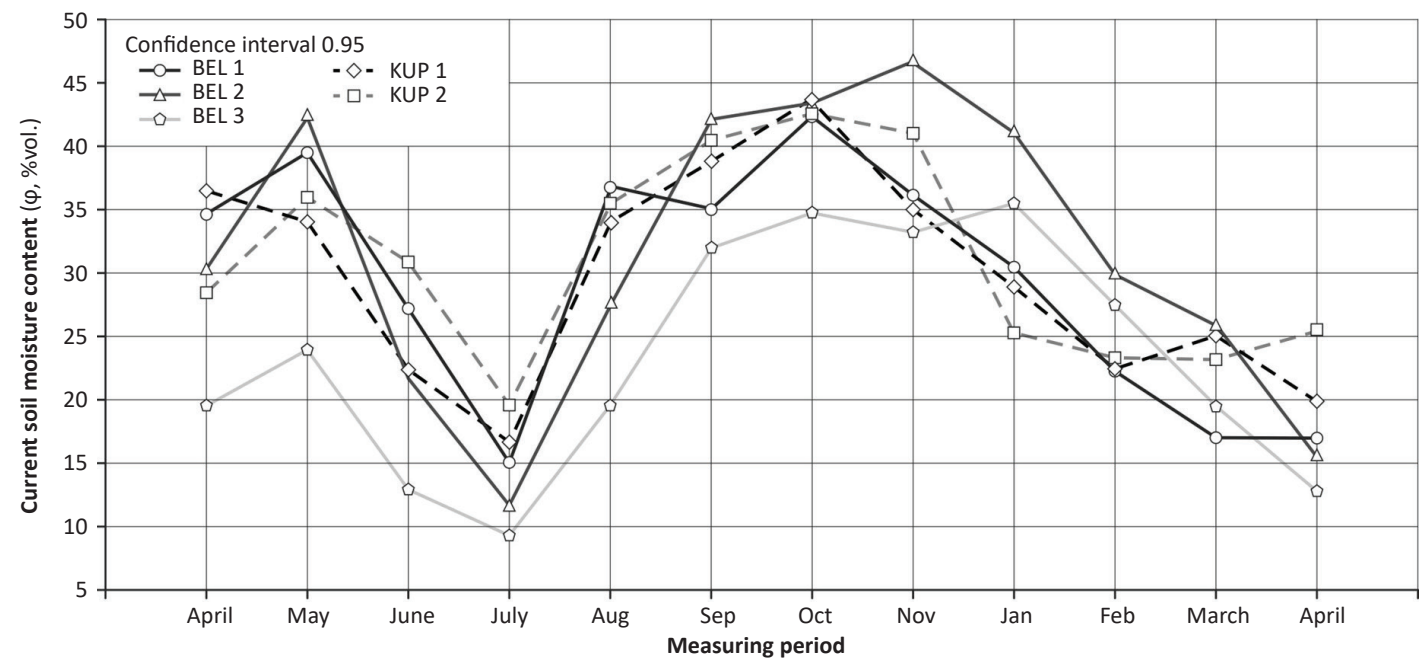

FIGURE 2. Average values of current soil moisture content on sampling plots 
Precipitation showed more considerable influence on soil moisture content than snow, whose climax was in January and which remained present in the forest stand till April.

\section{Penetration Resistance}

By repeated ANOVA analysis of soil penetration resistance, a statistically significant difference between sampling plots and the period of measurements was determined (Table 3).

Tukey Post Hoc test showed statistically significant differences between all five sampling plots at MS $=0.20571$ and $\mathrm{df}=2170$.

Figure 4 represents average values of soil penetration resistance per sampling plot in a given period of measurements. The peak of measurements was in July at $3 \mathrm{MPa}$, and the lowest value was measured at KUP 2 sampling plot in October $-0.62 \mathrm{MPa}$. The lowest average measurements for all five sampling plots were recorded in

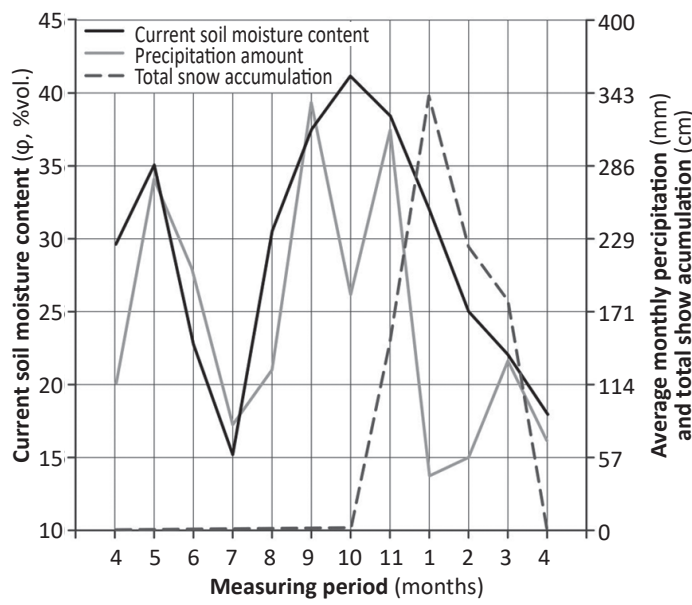

FIGURE 3. Average current moisture content and precipitation
January at $0.86 \mathrm{KPa}$. According to Bygdén's ground bearing capacity classification, all sampling plots (except KUP 2 in October) regardless the month, can be classified as medium hard to hard soils.

Average values of soil penetration resistance per plot and the period of measurements but depending of soil depth are given in Figure 5. By increasing soil depth, penetration resistance increases (Figure 5), and correlation coefficients show strong relationship (0.82-0.99) between these two variables. The highest average values were recorded in July and August from 1.62 $\mathrm{MPa}$ to $3 \mathrm{MPa}$ from the surface up to $30 \mathrm{~cm}$ depth. The lowest average values at the soil surface were in February and March, 0.35 MPa and $0.30 \mathrm{MPa}$ respectively. At $15 \mathrm{~cm}$ and $30 \mathrm{~cm}$ depth minimal values were recorded in October and January, $0.91 \mathrm{MPa}$ and 1.14 MPa respectively. The period of measurements and soil depth show lower influence on soil penetration resistance for sampling plots in MU "Kupjački vrh". On KUP 1 sampling plot the difference in soil penetration resistance between 10 $\mathrm{cm}$ and $30 \mathrm{~cm}$ depth ranges up to $0.45 \mathrm{Ma}$, while on KUP 2 sampling plot the difference is smaller and ranges up to 0.25 $\mathrm{MPa}$. On both sampling plots, the highest jump in penetration resistance is at first $10 \mathrm{~cm}$ of soil depth. On sampling plots in MU "Belevine" in a month of measurements there has been higher influence on penetration resistance ranging up to 1.0 $\mathrm{MPa}$.

By comparing the values of cone index at a depth of $15 \mathrm{~cm}\left(\mathrm{Cl}_{15}\right)$ and mean values between 5 and $25 \mathrm{~cm}$ of depth $\left(\mathrm{Cl}_{5-25}\right)$, the coefficient of variation (CV) indicates a lower variability of $\mathrm{Cl}_{5-25}$ values at four sampling plots from $14.56 \%$ to $22.84 \%$. At KUP 2 sampling plot variation coefficients of both cone indexes were the same. T-test, however, showed no statistically significant difference between the mean values of the cone index at a depth of 15 $\mathrm{cm}$ and 5 to $25 \mathrm{~cm}$.

\section{Shear Strength}

By repeated ANOVA analysis of shear strength a statistically significant difference between sites and the period of measurements was recorded (Table 4). Tukey Post

TABLE 3. ANOVA of soil penetration resistance (* symbolises significant difference).

\begin{tabular}{|c|c|c|c|c|c|}
\hline Effect & SS & DF & MS & $\mathbf{F}$ & $\mathbf{p}$ \\
\hline Intercept & $34988.12^{*}$ & $1^{*}$ & $34988.12 *$ & $170085.9 *$ & $0.00^{*}$ \\
\hline Sampling plot & $571.62 *$ & $4^{*}$ & $142.90 *$ & $694.7^{*}$ & $0.00^{*}$ \\
\hline Depth of measurements & $2131.69 *$ & $30 *$ & $71.06 *$ & $345.4^{*}$ & $0.00 *$ \\
\hline Sampling plot * Depth of measurements & $162.75^{*}$ & $120 *$ & $1.36^{*}$ & $6.6^{*}$ & $0.00^{*}$ \\
\hline Error & 446.39 & 2170 & 0.21 & & \\
\hline Period of measurements & $2749.35^{*}$ & $11^{*}$ & $249.94^{*}$ & $1549.0^{*}$ & $0.00^{*}$ \\
\hline Period of measurements * Sampling plot & $1561.96^{*}$ & $44^{*}$ & $35.50^{*}$ & $220.0^{*}$ & $0.00^{*}$ \\
\hline Period of measurements * Depth of measurements & $123.55^{*}$ & $330 *$ & $0.37^{*}$ & $2.3^{*}$ & $0.00 *$ \\
\hline Error & 3851.53 & 23870 & 0.16 & & \\
\hline
\end{tabular}




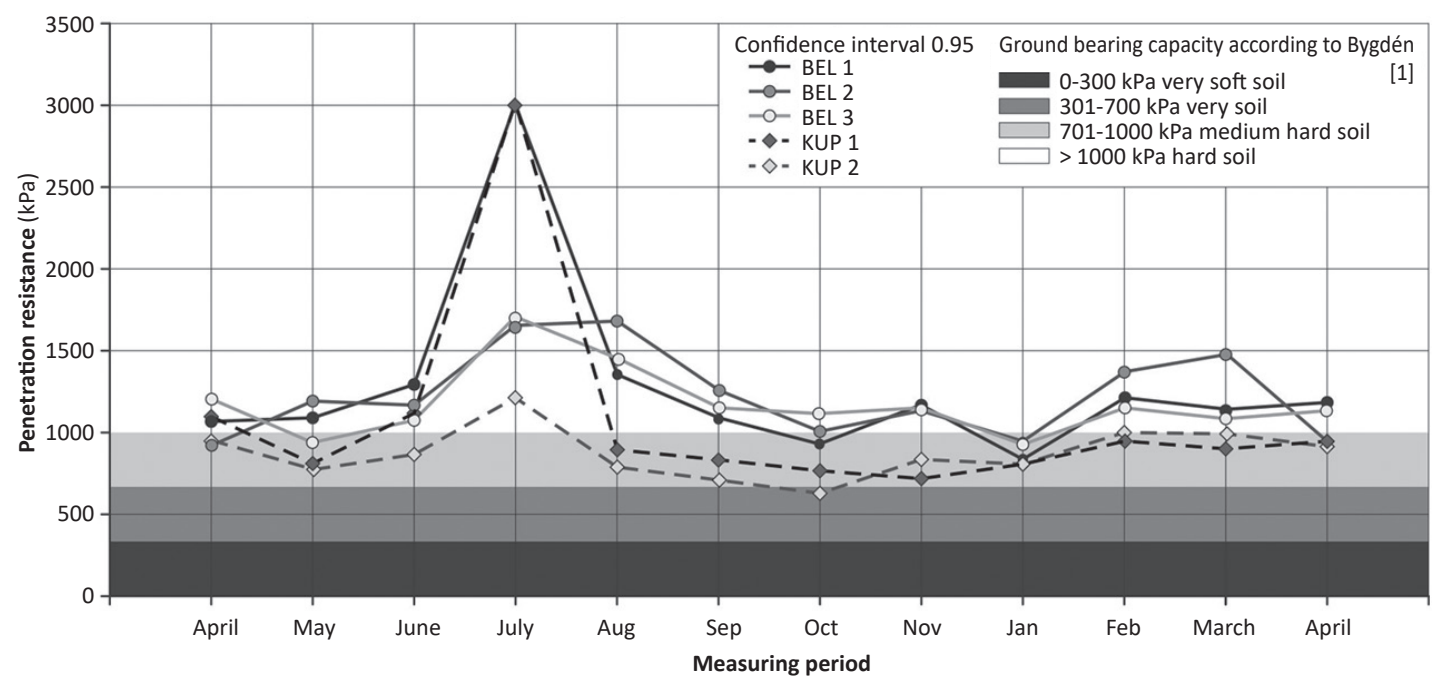

FIGURE 4. Soil penetration resistance per sampling plot in different months.

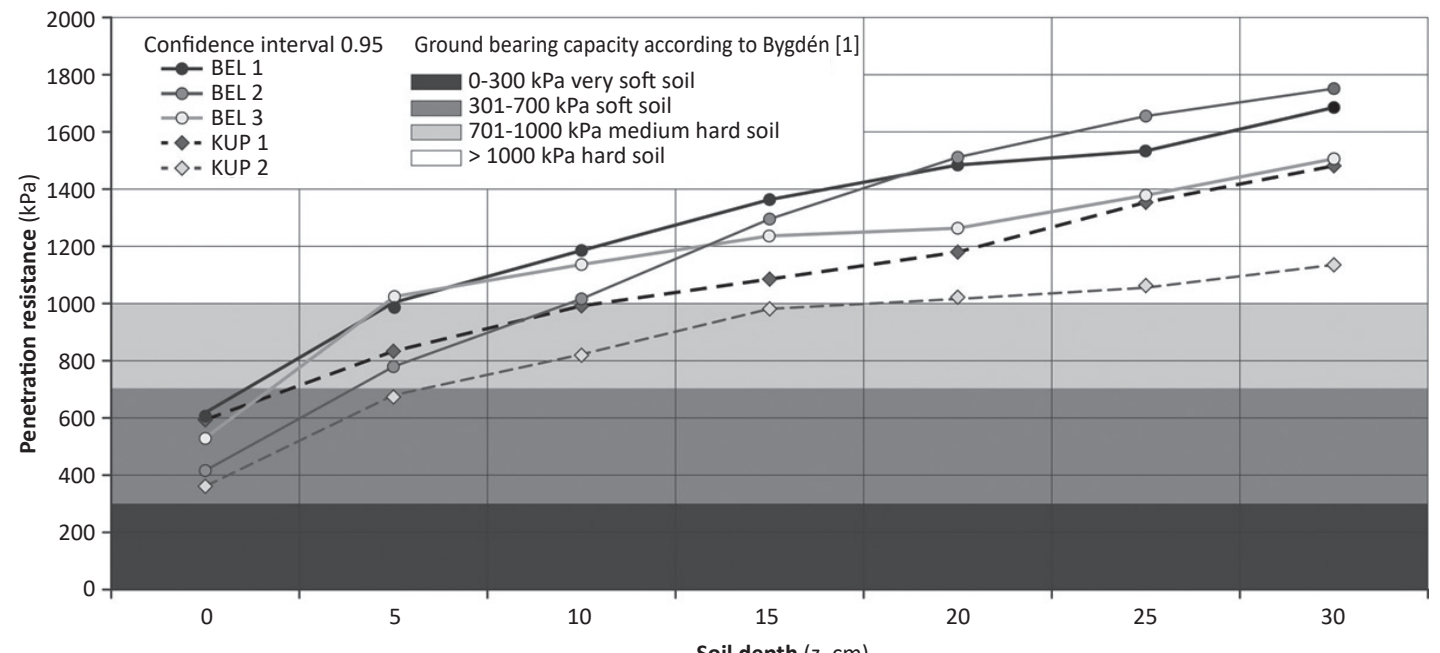

FIGURE 5. Differences in penetration resistance and soil depth.

Hoc test showed statistically significant difference between some sampling plots (Figure 6) at $\mathrm{MS}=234.07$ and $\mathrm{df}=70$, while there were no differences between sampling plots $B E L$ 1 and BEL 2, nor between BEL 3 and KUP 1.

The highest values of soil shear strength at $15 \mathrm{~cm}$ depth were recorded in July at $\tau=130 \mathrm{kPa}$, while the lowest values were recorded in May at $\operatorname{tmax}=61 \mathrm{kPa}$. If monthly mean values are compared to all five sampling plots, data deviation is visible, except in the summer months (July and August) when variation is at its minimum. The lowest mean values of the soil shear strength were measured on sampling plot KUP 1 ( $\tau=62 \mathrm{kPa})$, and the absolute minimum was measured in October ( $\tau=32 \mathrm{kPa})$.
When comparing cone index and shear strength to soil moisture (Figure 7) on all sampling plots during one-year period and in $15 \mathrm{~cm}$ depth, a consistency is evident. The years' peak of cone index $(\mathrm{Cl}=2109 \mathrm{kPa})$ and shear strength values $(\tau=129 \mathrm{kPa})$ in July was followed by a soil moisture minimum ( $\phi=15.26 \%)$, after which soil moisture content started to rise steadily, only to reach its high point in October at $\phi=41.21 \%$. In this period both the cone index and shear strength were descending and in October reached $891 \mathrm{kPa}$ and $87 \mathrm{kPa}$, respectively. After October soil moisture content plunged steeply only to be $\phi=18.05 \%$ in April. Cone index and shear strength fluctuated in this period from $997 \pm 120$ $\mathrm{kPa}$ and $100 \pm 7 \mathrm{kPa}$, respectively. 
TABLE 4. ANOVA of soil shear strength (* symbolises significant difference).

\begin{tabular}{|c|c|c|c|c|c|}
\hline Effect & SS & DF & MS & $\mathbf{F}$ & $\mathbf{p}$ \\
\hline Intercept & $7480225^{*}$ & $1^{*}$ & $7480225^{*}$ & $31956.63^{*}$ & $0.00^{*}$ \\
\hline Sampling plot & $40736 *$ & $4^{*}$ & $10184^{*}$ & $43.51 *$ & $0.00^{*}$ \\
\hline Error & 16385 & 70 & 234 & & \\
\hline Period of measurements & $300733^{*}$ & $11^{*}$ & $27339 *$ & 109.83* & $0.00^{*}$ \\
\hline Sampling plot * Period of measurements & $130620 *$ & $44^{*}$ & $2969 *$ & $11.93^{*}$ & $0.00^{*}$ \\
\hline Error & 191680 & 770 & 249 & & \\
\hline
\end{tabular}

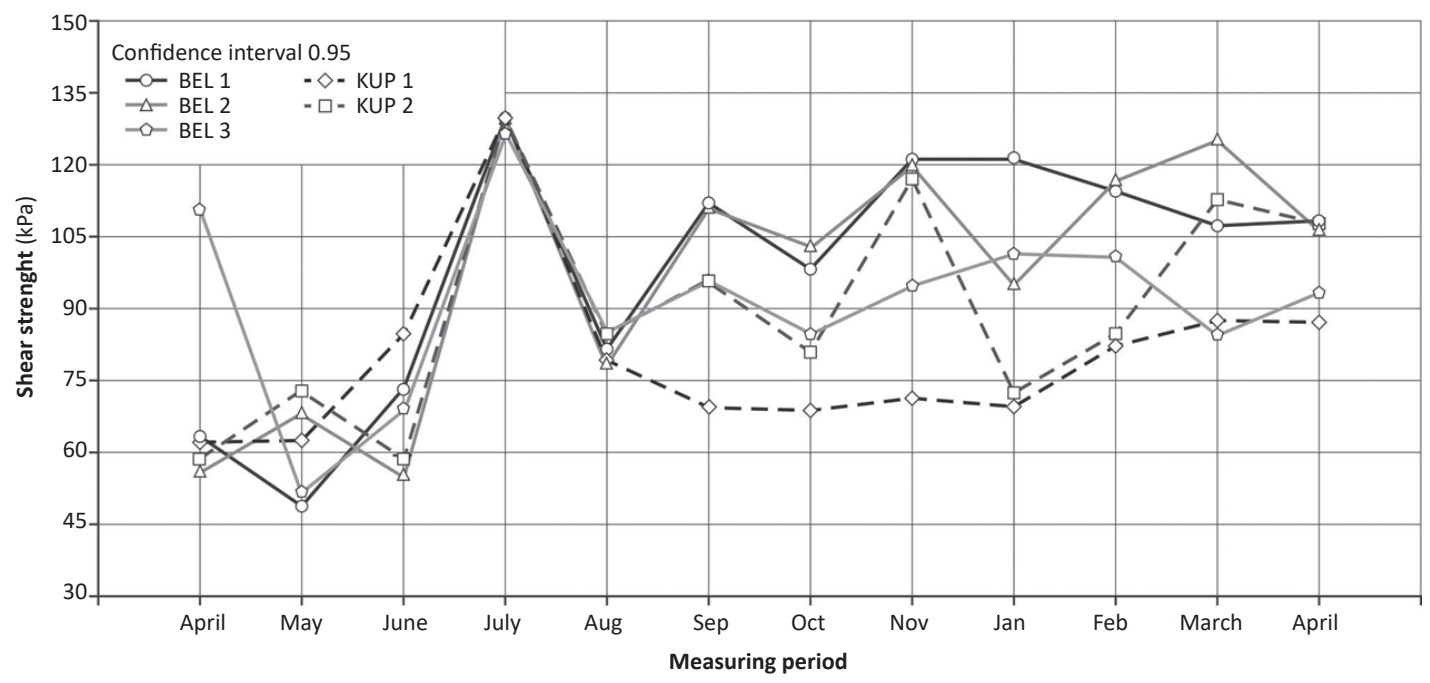

FIGURE 6. Soil shear strength during one-year period.
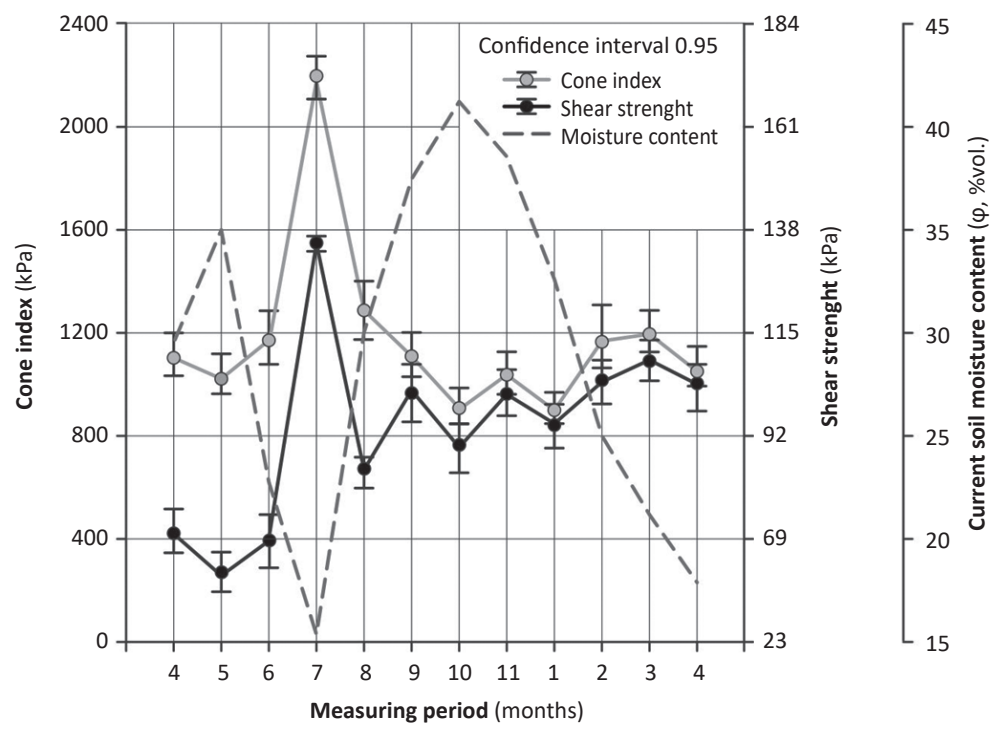

FIGURE 7. Soil measurements throughout the year. 


\section{DISCUSSION}

The correlation between soil moisture, precipitation and temperature data has been discussed widely [30, 31] and projects such as Global Soil Wetness Project (GSWP) reproduced the seasonal cycle of soil moisture [32]. To retrieve soil moisture, the effects of vegetation, surface roughness, and heterogeneous land cover must be taken into account [33], and in the territory of the Republic of Croatia, these data specific to forestry operations are still missing. There have been several studies on soil penetration resistance having water content or moisture content (MC) as an input variable $[34,35]$. The highest values of cone index and shear strength were recorded in July which was the warmest (above average) and driest (within average) month with only 7 rainy days. Current soil moisture was the lowest in July at $\phi=15.26 \%$ vol. Climate characteristics in Croatia have shown a trend of decreasing precipitation and increasing temperatures during all seasons in the $20^{\text {th }}$ century [36]. The lowest values of cone index were recorded from October to January with precipitation at its climax from September to January with cumulative 1232 $\mathrm{mm}$ of rain and $846 \mathrm{~cm}$ of snow. Even though soil moisture is a versatile parameter, data recorded by previous research and models combining cone index and soil moisture by Freitag [37] and Hinze's [38] are non-linear models which all give dependence between these parameters. Data analysis of penetration resistance showed statistically significant differences between five sampling plots, with their average at $1.12 \mathrm{MPa}$, which according to Bygdén [1] are hard soils with good bearing capacity. Lower values of penetration resistance were recorded in MU "Kupjački vrh" at $0.96 \mathrm{MPa}$, which is related to the overall terrain structure of high karst and surface roughness [28] in which the placement of sampling plots was difficult. Two chosen areas of KUP 1 and KUP 2 sampling plots were based on a search of deep soil exceptions so that measurements with digital penetrometer, vane tester and soil moisture meter could be achieved.

By comparing cone index values $\left(\mathrm{Cl}_{15}\right)$ and the mean values between 5 and $25 \mathrm{~cm}$ of depth $\left(\mathrm{Cl}_{5-25}\right)$, the variation coefficient indicates a lower variability of $\mathrm{Cl}_{5-25}$ values on four out of five sampling plots which correlate with a research by Pandur [39]. However, t-test showed no statistically significant difference between these soil parameters.

Even though soil penetration resistance was measured up to $80 \mathrm{~cm}$ of depth, the majority of changes in penetration resistance were in top 10 to $15 \mathrm{~cm}$ of soil after which curves stabilised and showed little to no difference depending on soil depth. Measurements up to $30 \mathrm{~cm}$ of soil depth are sufficient for operational forestry purposes [40-42] even though Jansson and Johansson [43] found that trafficincreased bulk density of a silt loam podzol was down to $40-50 \mathrm{~cm}$ of soil depth.
Vane tester in a simple way measures the unconfined shear strength of soil - soil cohesion [16], and gives the maximal strength that must be used to provoke a free movement of the soil. Formerly established dependence between penetration resistance and soil shear strength introduced by Meek [44] has shown its influence during field measurements (Figure 7). The lowest values of soil shear strength were recorded from April to June on average as $\tau=66 \mathrm{kPa}$, which according to Ward et al. [17] places these soils to high ground capacity category (H-GBC). Due to expressed doubts regarding the applicability of the mentioned categorisation in Croatian forestry, at least 80 $\mathrm{kPa}$ should be considered as medium hard soils, and values above $100 \mathrm{kPa}$ as hard soils.

\section{CONCLUSIONS}

Understanding terrain factors is critical for planning forest operations. Various stand conditions affect the type of machines, harvesting system and the activity itself regarding eco-efficiency, productivity, and revenue. Data regarding soil bearing capacity in a map form as an additional layer to other maps of stand characteristics would ensure better opportunities for planners or operators to reduce and avoid rutting and soil compaction. The measured data on penetration resistance, soil shear strength and current soil moisture have not only given in a simple and fast manner the in situ stand conditions, but have also shown their dependence on climatic conditions. In the absence of these data on the national level, particularly intended for forestry operations in which top $300 \mathrm{~mm}$ of soil are crucial, future research challenges should be addressed regarding: 1) the development of unified and straightforward methods for describing forest soil bearing capacity, 2) linking forest soil parameters to long-term monitoring of climatic elements, 3) connecting forest soil-bearing capacity to eco-indicators (occurrence of hygrophytes in forest phytocenoses), and 4) quantifying forest soil bearing capacity classification suitable for a wide range of conditions on the national level. Gaining knowledge on versatile soil bearing capacity throughout the calendar year would support route planning for primary and secondary traffic infrastructure network, as well as defining sensitive parts of logging areas and landing sites, and alarming machine operators to equip vehicles with wider tyres, chains or bogie tracks in specific conditions.

\section{Acknowledgments}

The study was carried out within the framework of "Optimisation of harvesting systems and forest traffic infrastructure on strategical and tactical level of planning" financed by the Croatian Ministry of Agriculture and non-market forest values. 


\section{REFERENCES}

1. BYGDÉN G 2012 GIS for Operative Support. In: Okia CA (ed) Global Perspectives on Sustainable Forest Management. IntechOpen Limited, London, UK, pp 217-222. DOI: https:// doi.org/10.5772/33230

2. TALBOT B, PIERZCHAŁA M, ASTRUP R 2017 Applications of remote and proximal sensing for improved precision in forest operations. Croat J For Eng 38 (2): 327-336

3. CUDZIK A, BRENNENSTHUL M, BIAŁCZYK W, CZARNECKI J 2017 Damage to Soil and Residual Trees Caused by Different Logging Systems Applied to Late Thinning. Croat J For Eng 38 (1): 83-95

4. OZTURK T 2016 The effects on soil compaction of timber skidding by tractor on skid road in plantation forest in northern Turkey. Sumar list 140 (9-10): 485-490

5. SOLGI A, NAGHDI R, TSIORAS PA, ILSTEDT U, SALEHI A, NIKOOY M 2017 Combined Effects of Skidding Direction, Skid Trail Slope and Traffic Frequency on Soil Disturbance in North Mountainous Forest of Iran. Croat J For Eng 38(1): 97-106.

6. CAMBI M, GRIGOLATO S, NERI F, PICCHIO R, MARCHI E 2016 Effects of forwarder operation on soil physical characteristics: a case study in the Italian alps. Croat J For Eng 37 (2): 233-239

7. SAARILAHTI M 2002 Modelling of the wheel and soil. Soil interaction model. Development of a protocol for ecoefficient wood harvesting on sensitive sites (Ecowood), Appendix report no 8, $37 \mathrm{p}$

8. PORŠINSKY T, STANKIĆ I, BOSNER A 2011 Ecoefficient timber forwarding based on nominal ground pressure analysis. Croat J For Eng 31 (1): 345-356

9. LÖFFLER HJ 1984 Terrain classification for forestry. Report TIM/EFC/WP.1/R.51, 24 August 1984, EU Timber Committee and FAO-ILO, $55 \mathrm{p}$

10. PORŠINSKY T 2005 Efficiency and environmental evaluation of Timberjack 1710 forwarder on roundwood extraction from Croatian lowland forests. PhD thesis, University of Zagreb, Faculty of Forestry, Zagreb, Croatia, $170 \mathrm{p}$

11. BALADI GY 1987 Terrain evaluation for off-road mobility. J Terramechanics 24 (2): 127-140. DOI: https://doi. org/10.1016/0022-4898(87)90003-6

12. HORVAT D 1996 Estimate of forest vehicle tractive performance based on cone penetrometer soil characteristic. Protection and utilisation of the Croatian forest resources from 1846 to 1996, Croatian Forestry Society, Zagreb, Croatia, pp 253-264

13. SAARILAHTI M 2002 Soil interaction model. Development of a protocol for ecoefficient wood harvesting on sensitive sites (Ecowood), Project deriverable D2, pp 1-87

14. KVASNIČKA P, KOVAČEVIĆ ZELIĆ B, DOMITROVIĆ D, VEINOVIĆ Ž, STRGAR H 2007 Soil mechanics 1. Faculty of Mining, Geology and Petroleum Engineering, Carnet, Zagreb, Croatia, $216 \mathrm{p}$

15. ASAE 1999 Procedures for using and reporting data obtained with the soil cone penetrometer (ASAE EP 542 FEB99). ASAE Standards 2000: 986-989.

16. SAARILAHTI M 2002 Soil interaction model. Development of a protocol for ecoefficient wood harvesting on sensitive sites (Ecowood), $87 \mathrm{p}$

17. WARD SM, OWENDE PMO 2003 Development of a protocol for eco-efficient wood harvesting on sensitive sites. In: Proceedings of the 2nd International Scientific Conference "Forest and Wood-Processing Technology vs. Environment - Fortechenvi Brno 2003", Brno, Czech Republic, 26-30 May 2003. Mendel University of Agriculture and Forestry Brno \& IUFRO WG 3.11.00, Brno, Czech Republic, 473-482
18. PORŠINSKY T, SRAKA M, STANKIĆ I 2006 Comparison of Two Approaches to Soil Strength Classifications. Croat J For Eng 27 (1): $17-26$

19. SAARILAHTI M 2002 Dynamic terrain classification Modelling of the seasonal variation of the trafficability on forest sites. Soil interaction model. Development of a protocol for ecoefficient wood harvesting on sensitive sites (Ecowood), Appendix report no. 1, $22 \mathrm{p}$

20. SHOOP S, YOUNG B, ALGER R, DAVIS J 1994 Effect of test method in winter traction measurements. J Terramechanics 31 (3): 156-162. DOI: https://doi.org/10.1016/00224898(94)90012-4

21. NUTTAL CJ, MCGOWAN RP 1962 Scale models of vehicles in soils and snows. In: Proceedings of 1st ISTVS Conference, Torino, Italy, pp 656-667

22. PANAGOS P, VAN LIEDEKERKE M, JONES A, MONTANARELLA L 2012 European Soil Data Centre: Response to European policy support and public data requirements. Land Use Policy 29 (2): 329-338. DOI: https://doi.org/10.1016/i. landusepol.2011.07.003

23. BOGUNOVIĆ M, VIDAČEK Ž, RACZ Z, HUSNJAK S, SRAKA M, 1997 The practical aspects of soil suitability map of Croatia. Agronomski glasnik: Glasilo Hrvatskog agronomskog društva 59 (5-6): 363-399

24. GRIGOLATO S, MOLOGNI O, CAVALLI R 2017 GIS applications in forest operations and road network planning: an overview over the last two decades. Croat J For Eng 38 (2): 175-186

25. SELETKOVIĆ Z, KATUŠIN Z 1992 Croatian Climate. In: Rauš $\bigoplus(e d)$ Forests in Croatia, Faculty of Forestry and Croatian forests Ltd., Zagreb, Croatia, pp 13-18

26. ANON 2009 Management program of forests with a specified use, forest training and research center Zalesina, MU Belevine 2010 - 2019. University of Zagreb, Faculty of Forestry, Zagreb, Croatia, $178 \mathrm{p}$

27. ĐUKA A, PORŠINSKY T, VUSIĆ D 2015 DTM models to enhance planning of timber harvesting. Bulletin of the Faculty of Forestry - University of Belgrade 2015: 35-44. DOI: https://doi.org/10.2298/GSF15S1035D

28. ĐUKA A, VUSIĆ D, PORŠINSKY T 2017 Terrain roughness evaluation for timber extraction by cable skidder. Gozdarski vestnik 75 (1): 21-35.

29. ĐUKA A, GRIGOLATO S, PAPA I, PENTEK T, PORŠINSKY T 2017 Assessment of timber extraction distance and skid road network in steep karst terrain. iForest 10 (6): 886-894. DOI: https://doi.org/10.3832/ifor2471-010

30. HENDERSON-SELLERS A 1996 Soil moisture: A critical focus for global change studies. Global Planet Change 13 (1-4): 3-9. DOI: https://doi.org/10.1016/0921-8181(95)00034-8

31. DAI A, TRENBERTH KE, QIAN T 2004 A global dataset of Palmer Drought Severity Index for 1870-2002: Relationship with soil moisture and effects of surface warming. J Hydrometeorol 5 (6): 1117-1130. DOI: https://doi. org/10.1175/JHM-386.1

32. ENTIN JK, ROBOCK, A, VINNIKOV KY, ZABELIN V, LIU S, NAMKHAI A, ADYASUREN T 1999 Evaluation of global soil wetness project soil moisture simulations. I Meteorol Soc Jpn 77 (1B): 183-198. DOI: https://doi.org/10.2151/ imsj1965.77.1B 183

33. WAGNER W, SCIPAL K, PATHE C, GERTEN D, LUCHT W, RUDOLF B 2003 Evaluation of the agreement between the first global remotely sensed soil moisture data with model and precipitation data. J Geophys Res-Atmos 108 (D19): 1-17. DOI: $\underline{\text { https://doi.org/10.1029/2003JD003663 }}$ 
34. AYERS PD, PERUMPRAL JV 1982 Moisture and density effect on cone index. Transactions of the ASAE 1982 (5): 1169-1972. DOI: https://doi.org/10.13031/2013.33691

35. SULLIVAN PM 1999 Impact of weather data accuracy on NRMMII vehicle performance predictions. In: Proceedings of the 13th International Conference of the ISVTS, Munich, Germany, 14-17 September 1999, pp 55-62

36. ZANINOVIĆ K, GAJIĆ-ČAPKA M 2000 Changes in components of the water balance in the Croatian lowlands. Theor Appl Climatol 65 (1-2): 111-117. DOI: https://doi. org/10.1007/s007040050008

37. FREITAG DR 1985 Soil dynamics as related to traction and transport systems. In: Proceedings of International Conference on Soil Dynamics, Auburn, Alabama, vol. 4: 605-629

38. HINZE D 1990 The influence of seasonal moisture changes on soil strength. In: Proceedings of the 10th International Conference of the ISVTS, Kobe, Japan, 20-24 August 1990, vol. 1: 107-116

39. PANDUR Z 2013 Application of commercial monitoring system for the purpose of study forwarder extracting features. PhD thesis, University of Zagreb, Faculty of Forestry, Zagreb, Croatia, $312 \mathrm{p}$
40. WILLIAMSON JR, NEILSEN WA 2000 The influence of forest site on rate and extent of soil compaction and profile disturbance of skid trails during ground-based harvesting. Can J For Res 30 (8): 1196-1205. DOI: https:// doi.org/10.1139/x00-041

41. LANDSBERG JD, MILLER RE, ANDERSON HW, TEPP JS 2003 Bulk density and soil resistance to penetration as affected by commercial thinning in north-eastern Washington. USDA For. Serv. Res. Pap. PNW-RP-551.

42. HAN S-K, HAN H-S, PAGE-DUMROESE DS, JOHNSON LR 2009 Soil compaction associated with cut-to-length and whole-tree harvesting of a coniferous forest. Can J For Res 39 (5): 976-989. DOI: https://doi.org/10.1139/X09-027

43. JANSSON K, JOHANSSON J 1998 Soil changes after traffic with a tracked and a wheeled forest machine: a case study on a silt loam in Sweden. Forestry 71 (1): 57-66. DOI: https://doi.org/10.1093/forestry/71.1.57

44. MEEK P 1996 Effects of skidder traffic on two types of forest soils. Forest Engineering Research Institute of Canada, Pointe-Claire, QC. Technical Report No. TR 117, 12 p 